\title{
Rare Earth Carbodiimide Silicates: RE2(CN2)(SiO4)
}

\begin{tabular}{|r|l|}
\hline Journal: & Zeitschrift für Anorganische und Allgemeine Chemie \\
\hline Manuscript ID: & zaac.201000013 \\
\hline Wiley - Manuscript type: & Article \\
\hline Date Submitted by the \\
Author: & 08-Jan-2010 \\
\hline Complete List of Authors: & Meyer, Hans-Juergen \\
\hline Keywords: & rare earth, carbodiimide, silicate \\
\hline
\end{tabular}

\section{S ScholaroNE" \\ Manuscript Central}




\title{
Rare Earth Carbodiimide Silicates: $\mathrm{RE}_{2}\left(\mathrm{CN}_{2}\right)\left(\mathrm{SiO}_{4}\right)$
}

\author{
Mariusz Kubus $^{[b][+]}$, Jochen Glaser ${ }^{[a]}$, Andrzej Kłonkowski ${ }^{[b]}$, and H.-Jürgen Meyer ${ }^{*[a]}$ \\ Dedicated to Professor Rüdiger Kniep on the occation of His $75^{\text {th }}$ Birthday
}

Keywords: Rare earth; Carbodiimide; Silicate; Metathesis, Structure elucidation, X-ray diffraction

\begin{abstract}
Rare earth carbodiimide silicates $\mathrm{RE}_{2}\left(\mathrm{CN}_{2}\right)\left(\mathrm{SiO}_{4}\right)$ with $\mathrm{RE}=\mathrm{Y}, \mathrm{La}$, and $\operatorname{Pr}$ where synthesized via solid state metathesis reactions of $\mathrm{RECl}, \mathrm{Li}_{2}\left(\mathrm{CN}_{2}\right)$, and $\mathrm{SiO}_{2}$ or $\mathrm{Li}_{2} \mathrm{SiO}_{4}$, respectively, in silica tubes at $550{ }^{\circ} \mathrm{C}$. All three compounds crystallize with different structures, although all of them represent distorted derivatives of the sodium chloride type structure. The structure of $\mathrm{Y}_{2}\left(\mathrm{CN}_{2}\right)\left(\mathrm{SiO}_{4}\right)$ was refined monoclinically $(C 2 / m, Z=2, a=1301.382(5) \mathrm{pm}, b=$ 377.630(1) pm, $\left.c=527.656(2) \mathrm{pm}, \beta=93.9816(2){ }^{\circ}\right)$ from $X$-ray powder data. The crystal structure of $\mathrm{La}_{2}\left(\mathrm{CN}_{2}\right)\left(\mathrm{SiO}_{4}\right)$ was refined in a different monoclinic space group $\left(P 2_{1} / c, Z=4, a=\right.$ 660.3(1) pm, $\left.b=1282.01(2) \mathrm{pm}, c=656.2(1) \mathrm{pm}, \beta=105.23(2){ }^{\circ}\right)$, and the structure of $\mathrm{Pr}_{2}\left(\mathrm{CN}_{2}\right)\left(\mathrm{SiO}_{4}\right)$ was refined triclinically $(P \overline{1}, \mathrm{Z}=2, a=646.7(2) \mathrm{pm}, b=669.2(2) \mathrm{pm}, c=$ $\left.671.8(2) \mathrm{pm}, \alpha=86.18(3)^{\circ}, \beta=73.22(3)^{\circ}, \gamma=74.08(3)^{\circ}\right)$ from X-ray single crystal data.
\end{abstract}

\author{
* Prof. Dr. H.-J. Meyer \\ Fax: +49-7071-29-5702 \\ E-mail: juergen.meyer@uni-tuebingen.de \\ [a] Abteilung für Festkörperchemie und Theoretische Anorganische Chemie \\ Institut für Anorganische Chemie \\ Ob den Himmelreich 7 \\ Eberhard-Karls-Universität Tübingen \\ D-72074 Tübingen, Germany \\ [b] Faculty of Chemistry \\ University of Gdańsk \\ Sobieskiego 18 \\ 80-952 Gdańsk, Poland \\ [+] jointly at University of Gdańsk and Tübingen
}

Wiley-VCH 


\section{Introduction}

A great deal of rare earth carbodiimide compounds was synthesized following solid state metathesis (SSM) reactions between rare earth trihalides and lithium carbodiiimide. On heating these mixtures, metathesis reactions reveal their characteristics, with a soft ignition coming about when heating up reaction mixtures into a temperature region within 450 to $550{ }^{\circ} \mathrm{C}$. The series of quasi-binary carbodiiimide $R E_{2}\left(\mathrm{CN}_{2}\right)_{3}$ compounds [1,2] with trivalent rare earth ions (RE $=\mathrm{Y}-\mathrm{Lu}$, except Pm, La) are fundamental examples of rare earth carbodiimide chemistry. But there are also multinary carbodiimide (or in some cases cyanamide) compounds represented by the formulas $\operatorname{REX}\left(\mathrm{CN}_{2}\right)(\mathrm{X}=\mathrm{Cl}, \mathrm{F})[3,4], \mathrm{RE}_{2} \mathrm{X}\left(\mathrm{CN}_{2}\right) \mathrm{N}(\mathrm{X}=\mathrm{Cl}, \mathrm{Br}, \mathrm{I})[5,6], \operatorname{LiRE}_{2} \mathrm{X}_{3}\left(\mathrm{CN}_{2}\right)_{2}(\mathrm{X}=\mathrm{F})$ [4], as well as very recently discovered compounds $\operatorname{LiRE}\left(\mathrm{CN}_{2}\right)_{2}(\mathrm{RE}=\mathrm{La}, \mathrm{Ce})$ and $\mathrm{Ce}_{3}\left(\mathrm{CN}_{2}\right)_{3} \mathrm{~N}$ [7]. All these compounds being obtained from SSM reactions, departing from different stoichiometries of $\mathrm{REX}_{3}$ and $\mathrm{Li}_{2}\left(\mathrm{CN}_{2}\right)$ mixtures, account for the rapid growth of this new family of rare earth carbodiimide compounds, and the thereon resting development of tetracyanamidosilicates [8].

An extension of this preparative concept to higher complexity comes about when another reaction partner is being introduced into a given SSM reaction. The introduction of oxide into a SSM reaction was previously explored with various oxygen sources in order to develop a high yield synthesis of $\mathrm{Y}_{2} \mathrm{O}_{2}\left(\mathrm{CN}_{2}\right)$ : Eu [9]. During reactions performed in silica tubes an unknown side phase appeared which later turned out to be $\mathrm{Y}_{2}\left(\mathrm{CN}_{2}\right)\left(\mathrm{SiO}_{4}\right)$, which was the starting point of this work.

Mixed anion compounds like $\mathrm{RE}_{2}\left(\mathrm{CN}_{2}\right)\left(\mathrm{SiO}_{4}\right)$ are known for various examples of rare earth orthosilicates containing yet another anion. The doubly charged carbodiimide ion and its assignment as a pseudo-chalcogenide [9, 10,11] leads to compounds having the general formula $\mathrm{RE}_{2} \mathrm{Ch}\left(\mathrm{SiO}_{4}\right)$ being known for $\mathrm{Ch}=\mathrm{O}$ [12], S [13], Se [14] and Te [15]. From a structural point of view, the compounds $\mathrm{RE}_{2} \mathrm{O}_{3}, \mathrm{RE}_{2} \mathrm{O}_{2} \mathrm{~S}$ and $\mathrm{RE}_{2} \mathrm{O}_{2}\left(\mathrm{CN}_{2}\right)$ have been shown to crystallize in closely related structures [9].

The luminescence behaviour of lanthanide-doped carbodiimide oxide compounds having the general formula $\mathrm{RE}_{2} \mathrm{O}_{2}\left(\mathrm{CN}_{2}\right)$ : $\mathrm{Ln}[16,17,18]$ provides an interesting potential of carbodiimide compounds. Moreover, the luminescence behaviour of $\mathrm{Y}_{2} \mathrm{O}_{2}\left(\mathrm{CN}_{2}\right)$ :Eu appears to be similar with that of the well-known red light emitter $\mathrm{Y}_{2} \mathrm{O}_{2} \mathrm{~S}: \mathrm{Eu}$ [9]. In addition, the rare earth silicates $\mathrm{Y}_{3} \mathrm{SiO}_{5}: \mathrm{Ln}(\mathrm{Ln}=\mathrm{Ce}$ or $\mathrm{Tb}$ ) are phosphors of current interest, being used in field emission displays (FEDs) [19].

In this work we present the novel $\mathrm{RE}_{2}\left(\mathrm{CN}_{2}\right)\left(\mathrm{SiO}_{4}\right)$ compounds, originally obtained from a reaction of rare earth carbodiimide with silica glass, and we describe the selective SSM preparations of these compounds, including their crystal structures.

\section{Experimental Section}




\section{Synthesis of $\mathrm{Li}_{4}\left(\mathrm{SiO}_{4}\right)$}

Lithium orthosilicate was prepared by solid state reaction on heating amorphous silica (Ventron, 99.9\%, -325 mesh) and lithium carbonate $\left(\mathrm{Li}_{2} \mathrm{CO}_{3}\right.$, Alfa, ultra pure). Amorphous silica and $\mathrm{Li}_{2} \mathrm{CO}_{3}$ were carefully mixed in an agate mortar in 1:2 molar ratio and heated at $800{ }^{\circ} \mathrm{C}$ for $4 \mathrm{~h}$ in air [20].

$$
\mathrm{SiO}_{2}+2 \mathrm{Li}_{2} \mathrm{CO}_{3} \rightarrow \mathrm{Li}_{4} \mathrm{SiO}_{4}+2 \mathrm{CO}_{2} \uparrow
$$

Lithium orthosilcate obtained from the reaction was $\mathrm{X}$-ray pure.

\section{Synthesis of $\mathrm{RE}_{2}\left(\mathrm{SiO}_{4}\right)\left(\mathrm{CN}_{2}\right)$}

Method 1: Reaction mixtures were prepared in an argon filled glove box starting from carefully homogenized mixtures of $\mathrm{RECl}_{3}$ (ABCR $99.9 \%$ ), $\mathrm{Li}_{2}\left(\mathrm{CN}_{2}\right)$ (prepared as previously reported [7]) and $\mathrm{SiO}_{2}$ (Ventron, 99.9\%, $\approx 325$ mesh). Reaction mixtures of $61.3 \mathrm{mg} \mathrm{LaCl} 3,61.8 \mathrm{mg} \mathrm{PrCl}_{3}$ and $48.8 \mathrm{mg} \mathrm{YCl}$, respectively, were loaded with $54 \mathrm{mg} \mathrm{Li}_{2} \mathrm{CN}_{2}, 15 \mathrm{mg} \mathrm{SiO}_{2}$ and $20 \mathrm{mg} \mathrm{KCl} \mathrm{(Merck,}$ p.a.) being carefully mixed and ground in a agate mortar. Each mixture was placed into a dry silica ampoule. Ampoules were evacuated, sealed under vacuum and heated up to $550{ }^{\circ} \mathrm{C}(5$ ${ }^{\circ} \mathrm{C} / \mathrm{min}$ ), held at this temperature for 3 days, and then cooled down to room temperature. The reaction products were washed with water several times, rinsed with ethanol, and dried at $85{ }^{\circ} \mathrm{C}$ in air. Results of powder XRD measurement revealed that the title compounds were the main crystalline products with estimated yields $>90 \%$.

Method 2: Reaction mixtures were prepared in an argon filled glove box starting from carefully homogenized mixtures of $\mathrm{RECl}_{3}, \mathrm{Li}_{2}\left(\mathrm{CN}_{2}\right)$ and $\mathrm{Li}_{4} \mathrm{SiO}_{4}$ being carefully mixed and ground in a agate mortar. Each mixture was placed into a dry silica ampoule. Ampoules were evacuated, sealed under vacuum and heated up to $550^{\circ} \mathrm{C}\left(5^{\circ} \mathrm{C} / \mathrm{min}\right)$, held at this temperature for 3 days, and then cooled down to room temperature. The reaction products were washed with water several times, rinsed with ethanol, and dried at $85{ }^{\circ} \mathrm{C}$ in air. Results of powder XRD measurement revealed reflections of the title compounds as the only crystalline products with estimated yields $>95 \%$.

\section{Powder X-Ray Diffraction}

The powder XRD patterns of all reaction products were collected with a Stadi-P (Stoe, Darmstadt) powder diffractometer using $\mathrm{Cu}-\mathrm{K}_{\alpha 1}(\lambda=154.06 \mathrm{pm})$ radiation (germanium monochromator). Most samples occurred to be X-ray pure, except for some samples being prepared following method 1 which were slightly contaminated with $\mathrm{Li}_{2} \mathrm{SiO}_{3}$.

The patterns were indexed by using the program system WinXPow [21]. The structure of $\mathrm{Y}_{2}\left(\mathrm{CN}_{2}\right)\left(\mathrm{SiO}_{4}\right)$ was indexed monoclinically with $a=1303.3(3) \mathrm{pm}, b=377.6(6) \mathrm{pm}, c=527.8(1)$ pm, $\beta=93.96(1){ }^{\circ}$ and $V=259.2(2) \AA^{3}$ based on 28 single indexed lines, $\operatorname{La}_{2}\left(\mathrm{CN}_{2}\right)\left(\mathrm{SiO}_{4}\right)$ was indexed monoclinically with $a=666.1$ (2) pm, $b=1282.0$.(3) pm, $c=651.8(2) \mathrm{pm}, \beta=105.13(1)^{\circ}$ and $V=537.4(3) \AA^{3}$ based on 37 single indexed lines, and $\operatorname{Pr}_{2}\left(\mathrm{CN}_{2}\right)\left(\mathrm{SiO}_{4}\right)$ was indexed 
triclinically with $a=646.5(3) \mathrm{pm}, b=670.0(5) \mathrm{pm}, c=671.5(4) \mathrm{pm}, \alpha=86.09(3) \stackrel{\circ}{,} \beta=73.29(2)$ ${ }^{\circ}, V=74.09(3)^{\circ}$ and $V=267.9(3) \AA^{3}$ based on 22 single indexed lines.

The crystal structure $\mathrm{Y}_{2}\left(\mathrm{CN}_{2}\right)\left(\mathrm{SiO}_{4}\right)$ was solved and refined in the monoclinic space group $\mathrm{C} 2 / \mathrm{m}$ from powder XRD data $(a=1301.38(7) \mathrm{pm}, b=377.63(2) \mathrm{pm}, c=527.66(3) \mathrm{pm}$ and $\beta=$ 93.982(4) ${ }^{\circ}, Z=2$ ) using the program packages EXPO [22] and Fullprof [23] based on 258 independent reflections and 40 refined parameters, yielding $\mathrm{R}_{\mathrm{Bragg}}=6.42$.

Positions of $\left(\mathrm{CN}_{2}\right)^{2-}$ and $\left(\mathrm{SiO}_{4}\right)^{4-}$ were refined in a disordered fashion on similar positions. No sign of a superstructure could be detected. Atom positions are listed in Table 2 and selected bond lengths are given in Table 3.

\section{Single-Crystal X-Ray Diffraction}

Colorless transparent crystals of $\mathrm{La}_{2}\left(\mathrm{CN}_{2}\right)\left(\mathrm{SiO}_{4}\right)$ and light green crystals of $\operatorname{Pr}_{2}\left(\mathrm{CN}_{2}\right)\left(\mathrm{SiO}_{4}\right)$ were selected from the reaction product and mounted on the tip of a glass fiber for a crystal structure determination. Intensity data were collected on a Stoe IPDS diffractometer using Mo- $\mathrm{K}_{\alpha}$ radiation. The data sets were corrected for Lorentz and polarization effects. Absorption corrections were carried out using crystal-shape optimization (X-Shape, X-RED). The program package SHELX97 [24] was used for crystal structure solutions and anisotropic refinements of all atoms. Some selected crystallographic data and some details of the structure refinements are listed in Table 1. Atomic positions and equivalent isotropic displacement parameters are given in Table 2, and a summary of selected bond lengths is given in Table 3.

Further details of the crystal-structure investigation may be obtained from the Fachinformationszentrum Karlsruhe, D-73644 Eggenstein-Leopoldshafen, Germany (fax: (+49)7247-808-666; e-mail: crysdata@fiz-karlsruhe.de), on quoting the depository number CSD420943 for $\mathrm{La}_{2}\left(\mathrm{CN}_{2}\right)\left(\mathrm{SiO}_{4}\right)$ and CSD-420944 for $\operatorname{Pr}_{2}\left(\mathrm{CN}_{2}\right)\left(\mathrm{SiO}_{4}\right)$.

\section{Results and Discussion}

Solid state metathesis reactions were used for the synthesis of three selected examples of hitherto unknown new rare earth carbodiimide silicates. Powders of $\mathrm{Y}_{2}\left(\mathrm{CN}_{2}\right)\left(\mathrm{SiO}_{4}\right)$ were originally obtained as a side phase from reactions of $\mathrm{YCl}_{3}$ and $\mathrm{Li}_{2}\left(\mathrm{CN}_{2}\right)$ with the wall of the silica container. This reaction was successfully reproduced in our synthesis described as method 1 in the experimental section by using small sized $\mathrm{SiO}_{2}$ as a reactant. Subsequent reactions described in method 2 are straight forward SSM reactions to combine a rare earth element (as $\mathrm{RECl}_{3}$ ) simultaneously with carbodiimide $\left(\right.$ as $\left.\mathrm{Li}_{2}\left(\mathrm{CN}_{2}\right)\right)$ and orthosilicate $\left(\right.$ as $\left.\mathrm{Li}_{4}\left(\mathrm{SiO}_{4}\right)\right)$ ions. Since $\mathrm{RE}_{2}\left(\mathrm{CN}_{2}\right)\left(\mathrm{SiO}_{4}\right)$ compounds behave stable in air and in water, the coproduced $\mathrm{LiCl}$ can be easily removed from the reaction products. The use of $\mathrm{KCl}$ in the reaction mixture was intended to allow better crystal growth, due to the formation of a $\mathrm{LiCl} / \mathrm{KCl}$ flux in course of the reaction. The 
example of our $\mathrm{RE}_{2}\left(\mathrm{CN}_{2}\right)\left(\mathrm{SiO}_{4}\right)$ synthesis provides a general concept for SSM reactions to obtain mixed anion compounds.

The three compounds $\mathrm{Y}_{2}\left(\mathrm{CN}_{2}\right)\left(\mathrm{SiO}_{4}\right), \mathrm{La}_{2}\left(\mathrm{CN}_{2}\right)\left(\mathrm{SiO}_{4}\right)$, and $\operatorname{Pr}_{2}\left(\mathrm{CN}_{2}\right)\left(\mathrm{SiO}_{4}\right)$ crystallize with three different crystal structures, all being related to the motif of the arrangement of ions in the $\mathrm{NaCl}$ type structure, where the centers of gravities of $\left(\mathrm{CN}_{2}\right)^{2-}$ and $\left(\mathrm{SiO}_{4}\right)^{4-}$ ions occupy anion positions in an alternating fashion. However, the structure refined for $\mathrm{Y}_{2}\left(\mathrm{CN}_{2}\right)\left(\mathrm{SiO}_{4}\right)$ revealed disordering of these anions, resulting in a picture in which anions superimpose each other at the same lattice voids. Although the refinement from powder data may reveal an intrinsically higher degree of uncertainty of a given structure refinement, no evidence for the presence of a superstructure was detectable from powder X-ray patterns. With respect to the difficulty related with this structure, we will only discuss the structures of $\mathrm{La}_{2}\left(\mathrm{CN}_{2}\right)\left(\mathrm{SiO}_{4}\right)$ and $\operatorname{Pr}_{2}\left(\mathrm{CN}_{2}\right)\left(\mathrm{SiO}_{4}\right)$ in more detail, with their structures being projected in Figures 1 and 2, in which the $\mathrm{NaCl}$ type related unit sections are emphasized as dotted lines. The alternating arrangements the two types of anions in the structures introduce a layered nature, being characterized by alternating $\left[R E\left(\mathrm{CN}_{2}\right)\right]^{+}$and $\left[\mathrm{RE}\left(\mathrm{SiO}_{4}\right)\right]^{-}$sequences (with $\mathrm{RE}=\mathrm{La}, \mathrm{Pr}$ ). As a consequence, the crystal structures of $\mathrm{RE}_{2}\left(\mathrm{CN}_{2}\right)\left(\mathrm{SiO}_{4}\right)$ contain two crystallographically distinct $\mathrm{RE}$ ions displayed in Figures 3 and 4. La1 is surrounded by four carbodiimide (La1-N: $265-284$ pm) and three silicate ions (La1-O: $242-283$ pm) and La2 by two carbodiimide (La2-N: $265-269$ pm) and four silicate ions (La2O: $238-288 \mathrm{pm}$ ), whereas silicate groups connect via one or two oxygen atoms with one and the same lanthanum atom. The coordination environment of Pr1 involves two carbodiimide (Pr1$\mathrm{N}: 252-257 \mathrm{pm}$ ) and four silicate ions (Pr1-O: $228-275$ pm) and Pr2 is surrounded by three carbodiimide (Pr2-N: $253-270$ pm) and three silicate ions (Pr2-O: $244-264$ pm).

Each of the presented $\mathrm{RE}_{2}\left(\mathrm{CN}_{2}\right)\left(\mathrm{SiO}_{4}\right)$ structure contains one distinguishable $[\mathrm{NCN}]^{2-}$ ion, having $\mathrm{N}-\mathrm{C}-\mathrm{N}$ bond angles of $177(1){ }^{\circ}$ with $\mathrm{C}-\mathrm{N}$ bond length of $121(2), 126(2) \mathrm{pm}$ for RE $=\mathrm{La}$, and $\mathrm{N}-$ C-N bond angles of $176.4(8){ }^{\circ}$ with $\mathrm{C}-\mathrm{N}$ bond length of $125(1), 122(4)$ pm for RE $=\mathrm{Pr}$. In spite of their significant deviations from ideal $\mathrm{D}_{\infty \mathrm{h}}$ symmetry, the $[\mathrm{N}=\mathrm{C}=\mathrm{N}]^{2-}$ ions are considered as carbodiimide ions (rather than cyanamide) for reasons discussed previously [7].

Acknowledgement. The authors like to thank the Deutsche Forschungsgemeinschaft (Bonn) for support of this research. 
Table 1. Single crystal data on structure refinements on $R_{2}\left(C_{2}\right)\left(\mathrm{SiO}_{4}\right)$ with $\mathrm{RE}=\mathrm{La}, \operatorname{Pr}$. $\mathrm{P} \overline{1}$

\begin{tabular}{|c|c|c|}
\hline Empirical formula & $\mathrm{La}_{2}\left(\mathrm{CN}_{2}\right)\left(\mathrm{SiO}_{4}\right)$ & $\operatorname{Pr}_{2}\left(\mathrm{CN}_{2}\right)\left(\mathrm{SiO}_{4}\right)$ \\
\hline Formula weight $/ \mathrm{g} / \mathrm{mol}$ & 409.94 & 413.94 \\
\hline Temperature / K & 293(2) & 293(2) \\
\hline Wavelength / $\AA$ & 0.71073 & 0.71073 \\
\hline Crystal system & monoclinic & triclinic \\
\hline Space group (No.) & $P 2_{1} / c(14)$ & $P \overline{1}$ \\
\hline \multirow[t]{3}{*}{ Unit cell dimensions / pm or ${ }^{\circ}$} & $a=660.3(1)$ & $a=646.7(2), \alpha=86.18(3)$ \\
\hline & $b=1282.0(2), B=105.23(2)$ & $b=669.2(2), \beta=73.22(3)$ \\
\hline & $c=656.2(1)$ & $c=671.8(2), \mathrm{Y}=74.08(3)$ \\
\hline Volume $/ 10^{6} \mathrm{pm}^{3}$ & $535.9(2)$ & $267.7(1)$ \\
\hline Z & 4 & 2 \\
\hline Density (calculated) $/ \mathrm{g} / \mathrm{cm}^{3}$ & 5.081 & 5.136 \\
\hline Absorption coefficient / $\mathrm{mm}^{-1}$ & 15.891 & 18.150 \\
\hline$F(000)$ & 720 & 368 \\
\hline Crystal size $/ \mathrm{mm}^{3}$ & $0.14 \times 0.13 \times 0.04$ & $0.12 \times 0.10 \times 0.06$ \\
\hline Theta range for data collection $/{ }^{\circ}$ & 3.18 to 24.71 & 3.17 to 25.04 \\
\hline Index ranges & $-7 \leq \mathrm{h} \leq 7,-15 \leq \mathrm{k} \leq 15,-7 \leq \mathrm{I} \leq 7$ & $-7 \leq \mathrm{h} \leq 7,-7 \leq \mathrm{k} \leq 7,-7 \leq \mathrm{I} \leq 7$ \\
\hline Reflections collected & 5318 & 2710 \\
\hline Independent reflections & $939[\mathrm{R}(\mathrm{int})=0.0883]$ & $884[R($ int $)=0.0271]$ \\
\hline Completeness to theta & $100.0 \%$ & $93.3 \%$ \\
\hline Refinement method & Full-matrix least-squares on $\mathrm{F}^{2}$ & Full-matrix least-squares on $\mathrm{F}^{2}$ \\
\hline Data / restraints / parameters & 939 / 0 / 92 & 884 / 0 / 91 \\
\hline Goodness-of-fit on $F^{2}$ & 1.114 & 1.293 \\
\hline \multirow[t]{2}{*}{ Final $R$ indices $[I>2 \sigma(I)]$} & $\mathrm{R} 1=0.0375$ & $\mathrm{R} 1=0.0244$ \\
\hline & $w R 2=0.1057$ & $w R 2=0.0665$ \\
\hline \multirow[t]{2}{*}{$\mathrm{R}$ indices (all data) } & $R 1=0.0379$ & $\mathrm{R} 1=0.0257$ \\
\hline & $w R 2=0.1064$ & $w R 2=0.0670$ \\
\hline $\begin{array}{l}\text { Largest diff. peak and hole / e/10 } \\
\mathrm{pm}^{3}\end{array}$ & 2.127 and -2.910 & 1.047 and -2.726 \\
\hline
\end{tabular}


Table 2. Atomic coordinates and equivalent isotropic displacement parameters $\left(10^{4} \mathrm{pm}^{2}\right)$ for $\mathrm{RE}_{2}\left(\mathrm{CN}_{2}\right)\left(\mathrm{SiO}_{4}\right)(\mathrm{RE}=\mathrm{La}, \mathrm{Pr}) . \mathrm{U}_{\text {eq }}$ is defined as one third of the trace of the orthogonalized $U_{i j}$ tensor. Isotropic displacement parameters $U_{\text {iso }}\left(10^{4} \mathrm{pm}^{2}\right)$ are given for $\mathrm{RE}=\mathrm{Y}$.

\section{$\mathrm{La}_{2}\left(\mathrm{CN}_{2}\right)\left(\mathrm{SiO}_{4}\right)$}

\begin{tabular}{lllll}
\hline Atom & $x$ & $y$ & $z$ & $\mathrm{U}_{\text {eq }}$ \\
La1 & $0.4131(1)$ & $0.09933(6)$ & $0.2186(1)$ & $0.0144(3)$ \\
La2 & $0.0294(1)$ & $-0.1454(1)$ & $0.3295(1)$ & $0.0151(3)$ \\
Si & $0.0924(6)$ & $-0.0995(3)$ & $0.8115(6)$ & $0.0150(8)$ \\
O1 & $0.105(2)$ & $0.0532(8)$ & $0.370(1)$ & $0.017(2)$ \\
O2 & $0.253(2)$ & $-0.0075(8)$ & $-0.085(2)$ & $0.024(2)$ \\
O3 & $-0.026(2)$ & $-0.1656(7)$ & $-0.042(2)$ & $0.016(2)$ \\
O4 & $0.222(2)$ & $-0.1802(8)$ & $0.705(2)$ & $0.015(2)$ \\
C & $-0.474(2)$ & $-0.152(1)$ & $0.272(2)$ & $0.017(3)$ \\
N1 & $-0.574(2)$ & $-0.0974(9)$ & $0.360(2)$ & $0.024(3)$ \\
N2 & $-0.372(2)$ & $-0.2047(9)$ & $0.172(2)$ & $0.019(3)$ \\
\hline
\end{tabular}

\section{$\operatorname{Pr}_{2}\left(\mathrm{CN}_{2}\right)\left(\mathrm{SiO}_{4}\right)$}

\begin{tabular}{lllll}
\hline Atom & $x$ & $y$ & $z$ & $U_{\text {eq }}$ \\
Pr1 & $0.06189(5)$ & $0.23652(5)$ & $0.33127(5)$ & $0.0068(2)$ \\
Pr2 & $0.45537(5)$ & $0.31934(6)$ & $-0.21243(5)$ & $0.0084(2)$ \\
Si & $-0.0428(3)$ & $0.2955(3)$ & $-0.1844(3)$ & $0.0072(4)$ \\
O1 & $0.1118(8)$ & $-0.1304(8)$ & $0.3035(7)$ & $0.010(1)$ \\
O2 & $-0.1359(7)$ & $0.6117(7)$ & $0.3701(7)$ & $0.0089(9)$ \\
O3 & $0.0896(8)$ & $0.2237(8)$ & $-0.0145(7)$ & $0.011(1)$ \\
O4 & $0.2758(8)$ & $0.5199(8)$ & $0.1105(7)$ & $0.011(1)$ \\
C & $0.563(1)$ & $0.178(1)$ & $0.303(1)$ & $0.010(2)$ \\
N1 & $0.478(1)$ & $0.070(1)$ & $0.236(1)$ & $0.019(2)$ \\
N2 & $0.6401(9)$ & $0.299(1)$ & $0.3758(9)$ & $0.011(1)$ \\
\hline
\end{tabular}




\section{$\mathrm{Y}_{2}\left(\mathrm{CN}_{2}\right)\left(\mathrm{SiO}_{4}\right)$}

\begin{tabular}{llllll}
\hline Atom & $x$ & $y$ & $z$ & $\mathrm{U}_{\text {iso }}$ & Occ. \\
$\mathrm{Y}$ & $0.1291(1)$ & 0 & $0.3749(3)$ & $0.0063(5)$ & 1 \\
$\mathrm{Si}$ & $0.0930(6)$ & $1 / 2$ & $0.819(2)$ & $0.003(3)$ & 0.5 \\
$\mathrm{O} 1$ & $0.116(2)$ & $1 / 2$ & $0.108(5)$ & $0.023(4)$ & 0.5 \\
$\mathrm{O} 2$ & $0.203(2)$ & $1 / 2$ & $0.656(5)$ & $0.016(4)$ & 0.5 \\
$\mathrm{O} 3$ & $0.0352(6)$ & $0.136(2)$ & $0.730(1)$ & $0.013(3)$ & 0.5 \\
$\mathrm{C}$ & $0.155(2)$ & $1 / 2$ & $0.865(6)$ & $0.02(1)$ & 0.5 \\
$\mathrm{~N} 1$ & $0.152(2)$ & $1 / 2$ & $0.090(5)$ & $0.023(4)$ & 0.5 \\
$\mathrm{~N} 2$ & $0.177(2)$ & $1 / 2$ & $0.643(6)$ & $0.016(4)$ & 0.5 \\
\hline
\end{tabular}


Table 3. Selected bond lengths (pm) and angles ( $\left.{ }^{\circ}\right)$ for $\mathrm{RE}_{2}\left(\mathrm{CN}_{2}\right)\left(\mathrm{SiO}_{4}\right)$ compounds.

\begin{tabular}{|c|c|c|c|c|c|c|}
\hline \multicolumn{2}{|c|}{$\mathrm{La}_{2}\left(\mathrm{CN}_{2}\right)\left(\mathrm{SiO}_{4}\right)$} & \multicolumn{2}{|c|}{$\mathrm{Pr}_{2}\left(\mathrm{CN}_{2}\right)\left(\mathrm{SiO}_{4}\right)$} & \multicolumn{3}{|c|}{$\mathrm{Y}_{2}\left(\mathrm{CN}_{2}\right)\left(\mathrm{SiO}_{4}\right)$} \\
\hline La1-O1 & $256(1)$ & Pr1-O1 & $\begin{array}{l}253.0(5) \\
240.0(5)\end{array}$ & $\mathrm{Y}-\mathrm{O} 1$ & $235(2)$ & $2 x$ \\
\hline La1-O2 & $\begin{array}{l}242(1) \\
283(1)\end{array}$ & Pr1-O2 & $\begin{array}{l}247.8(5) \\
252.5(5)\end{array}$ & $\mathrm{Y}-\mathrm{O} 2$ & $\begin{array}{l}255(2) \\
221(3)\end{array}$ & $2 x$ \\
\hline La1-O3 & $265(1)$ & Pr1-O3 & $228.3(5)$ & $\mathrm{Y}-\mathrm{O} 3$ & $\begin{array}{l}236.4(8) \\
223.1(8)\end{array}$ & $\begin{array}{l}2 x \\
2 x\end{array}$ \\
\hline La1-O4 & $255(1)$ & Pr1-O4 & $275.5(5)$ & & & \\
\hline La1-N1 & $\begin{array}{l}268(1) \\
269(1)\end{array}$ & Pr1-N1 & $251.8(6)$ & Y-N1 & $244(2)$ & $2 x$ \\
\hline La1-N2 & $\begin{array}{l}265(1) \\
284(1)\end{array}$ & Pr1-N2 & $257.4(6)$ & Y-N2 & $\begin{array}{l}254(2) \\
241(2)\end{array}$ & $2 x$ \\
\hline La2-O1 & $\begin{array}{l}260(1) \\
264(1)\end{array}$ & Pr2-O1 & $264.2(5)$ & & & \\
\hline La2-O2 & $288(1)$ & Pr2-O2 & $250.6(5)$ & & & \\
\hline La2-O3 & $\begin{array}{c}238(1) \\
262.3(9)\end{array}$ & Pr2-O3 & $258.3(5)$ & & & \\
\hline La2-O4 & $\begin{array}{l}250(1) \\
280(1)\end{array}$ & Pr2-O4 & $\begin{array}{l}243.6(5) \\
254.2(5)\end{array}$ & & & \\
\hline La2-N1 & $265(1)$ & Pr2-N1 & $252.7(7)$ & & & \\
\hline La2-N2 & $269(1)$ & Pr2-N2 & $\begin{array}{l}267.4(6) \\
269.7(6)\end{array}$ & & & \\
\hline Si-O1 & $162.9(9)$ & Si-O1 & $162.9(5)$ & Si-O1 & 154(3) & \\
\hline $\mathrm{Si}-\mathrm{O} 2$ & 161(1) & Si-O2 & $165.4(5)$ & Si-O2 & 172(3) & \\
\hline $\mathrm{Si}-\mathrm{O} 3$ & 163(1) & $\mathrm{Si}-\mathrm{O} 3$ & $159.2(5)$ & $\mathrm{Si}-\mathrm{O} 3$ & $162.0(9)$ & $2 x$ \\
\hline $\mathrm{Si}-\mathrm{O} 4$ & 162(1) & $\mathrm{Si}-\mathrm{O} 4$ & $163.4(5)$ & & & \\
\hline C-N1 & 121(2) & $\mathrm{C}-\mathrm{N} 1$ & 120(1) & $\mathrm{C}-\mathrm{N} 1$ & $119(4)$ & \\
\hline C-N2 & 126(2) & C-N2 & 125(1) & $\mathrm{C}-\mathrm{N} 2$ & 122(4) & \\
\hline N1-C-N2 & $177(2)$ & N1-C-N2 & $176.4(8)$ & N1-C-N2 & 169(5) & \\
\hline
\end{tabular}




\section{References}

[1] M. Neukirch, S. Tragl, H.-J. Meyer, Inorg. Chem. 2006, 45, 8188.

[2] J. Glaser, L. Unverfehrt, H. Bettentrup, G. Heymann, H. Huppertz, T. Jüstel, H.-J. Meyer, Inorg. Chem. 2008, 47, 10455.

[3] R. Srinivasan, J. Glaser, S. Tragl, H.-J. Meyer, Z. Anorg. Allg. Chem. 2005, 631, 479.

[4] L. Unverfehrt, J. Glaser, M. Ströbele, S. Tragl, K. Gibson, H.-J. Meyer, Z. Anorg. Allg. Chem. 2009, 635, 479.

[5] R. Srinivasan, M. Ströbele, H.-J. Meyer, Inorg. Chem. 2003, 42, 3406.

[6] R. Srinivasan, Dissertation, Univ. Tübingen, 2004.

[7] L. Unverfehrt, M. Ströbele, J. Glaser, H.-J. Meyer, Z. Anorg. Allg. Chem. 2009, 635, 1947.

[8]J. Glaser, S. Tragl, H.-J. Meyer, Angew. Chem. 2008, 120, 7658; Angew. Chem. Int. Ed. Engl. 2008, 47, 7547.

[9] J. Sindlinger, J. Glaser, H. Bettentrup, T. Jüstel, H.-J. Meyer, Z. Anorg. Allg. Chem. 2007, 633, 1686.

[10]] X. Liu, M. Krott, P. Müller, C. Hu, H. Lueken, R. Dronskowski, Inorg. Chem. 2005, 44, 3001.

[11] X. Liu, M. Krott, L. Stork, M. Speldrich, H. Lueken, R. Dronskowski, Chem. Eur. J. 2009, 15, 1558.

[12] H. Müller-Bunz, T. Schleid, Z. Anorg. Allg. Chem. 1999, 625, 613; I. Hartenbach, S.F. Meier, J. Wontcheu, T. Schleid, Z. Anorg. Allg. Chem. 2002, 628, 2907.

[13] I. Hartenbach, P. Lauxmann, T. Schleid, Z. Anorg. Allg. Chem. 2004, 630, 1408.

[14] M. Gruppe, W. Urland, Z. Naturforsch. 1989, 45b, 456.

[15] H. Person, M. Grupe, W. Urland, Z. Anorg. Allg. Chem. 2000, 626, 280.

[16] E. Säilynoja, M. Lastusaari, J. Hölsä, P. Porcher, J. Lumin. 1997, 210, 72.

[17] J. Hölsä, R.-J. Lamminmäki, M. Lastusaari, E. Säilynoja, P. Porcher, Spectrochim. Acta A 1998, 54, 2065.

[18] M. Takahashi, Y. Hashimoto, S. Kikkawa, H. Kobayashi, Zairyo 2000, 49, 1230.

[19] T. Jüstel, H. Nikol, C. Ronda, Angew. Chem. Int. Ed. 1998, 37, 3097.

[20] T. Tang, Z. Zhang, J.-B. Meng, D.-L. Luo, Fus. Eng. Des. 2009, article in press.

[21] WinXPow, Version 1.10: Diffractometer Software, Stoe \& Cie GmbH, Darmstadt, Germany, 2001.

[22] A: Altomare, M.C. Burla, G. Cascarano, C. Giacovazzo, A. Guagliardi, A.G.G. Moliterni, G. Polidori: "Extra: a Program for extracting Structure-Factor Amplitudes from Powder Diffraction Data”, J. Appl. Cryst. 1995, 28, 842; A. Altomare, G. Cascarano, C. Giacovazzo, A. Guagliardi, M.C. Burla, G. Polidori, M. Camalli: "SIRPOW.92 - a program for automatic solution of crystal structures by direct methods optimized for powder data", J. Appl. Cryst. 1994, 27, 435. 
[23] J. Rodriguez-Carvajal, T. Roisnel, FullProf and WinPLOTR, Windows Applications for Powder Diffraction Patterns Analysis, France, 2006. T. Roisnel and J. Rodríguez-Carvajal, WinPLOTR: a Windows tool for powder diffraction patterns analysis, Materials Science Forum, Proceedings of the Seventh European Powder Diffraction Conference (EPDIC 7), 2000, 118, Ed. R. Delhez and E.J. Mittenmeijer.

[24] G.M. Sheldrick, SHELX-97: Program Package for Crystal Structure Determination, University of Göttingen, Göttingen, Germany, 1997.

\section{Figure Captions}

Figure 1. Crystal structure of $\mathrm{La}_{2}\left(\mathrm{CN}_{2}\right)\left(\mathrm{SiO}_{4}\right)$. The $\mathrm{NaCl}$ type related unit cell is indicated by the dotted line, with La1 at the corner.

Figure 2. Crystal structure of $\operatorname{Pr}_{2}\left(\mathrm{CN}_{2}\right)\left(\mathrm{SiO}_{4}\right)$. The $\mathrm{NaCl}$ type related unit cell is indicated by the dotted line, with Pr2 at the corner.

Figure 3. Coordination environment of lanthanum ions in the structure of $\mathrm{La}_{2}\left(\mathrm{CN}_{2}\right)\left(\mathrm{SiO}_{4}\right)$.

Figure 4. Coordination environment of praseodymium ions in the structure of $\operatorname{Pr}_{2}\left(\mathrm{CN}_{2}\right)\left(\mathrm{SiO}_{4}\right)$. 


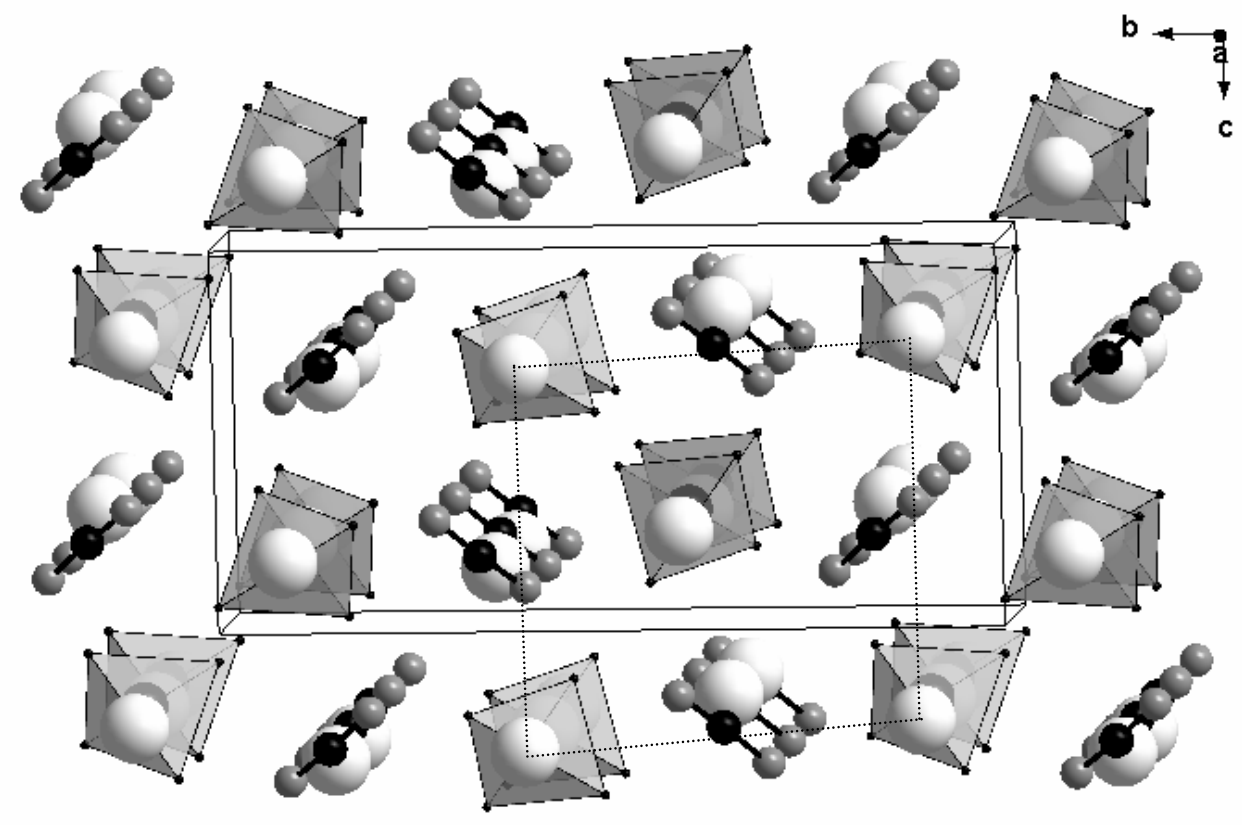

Figure 1. Crystal structure of $\mathrm{La}_{2}\left(\mathrm{CN}_{2}\right)\left(\mathrm{SiO}_{4}\right)$. The $\mathrm{NaCl}$ type related unit cell is indicated by the dotted line, with La1 at the corner.

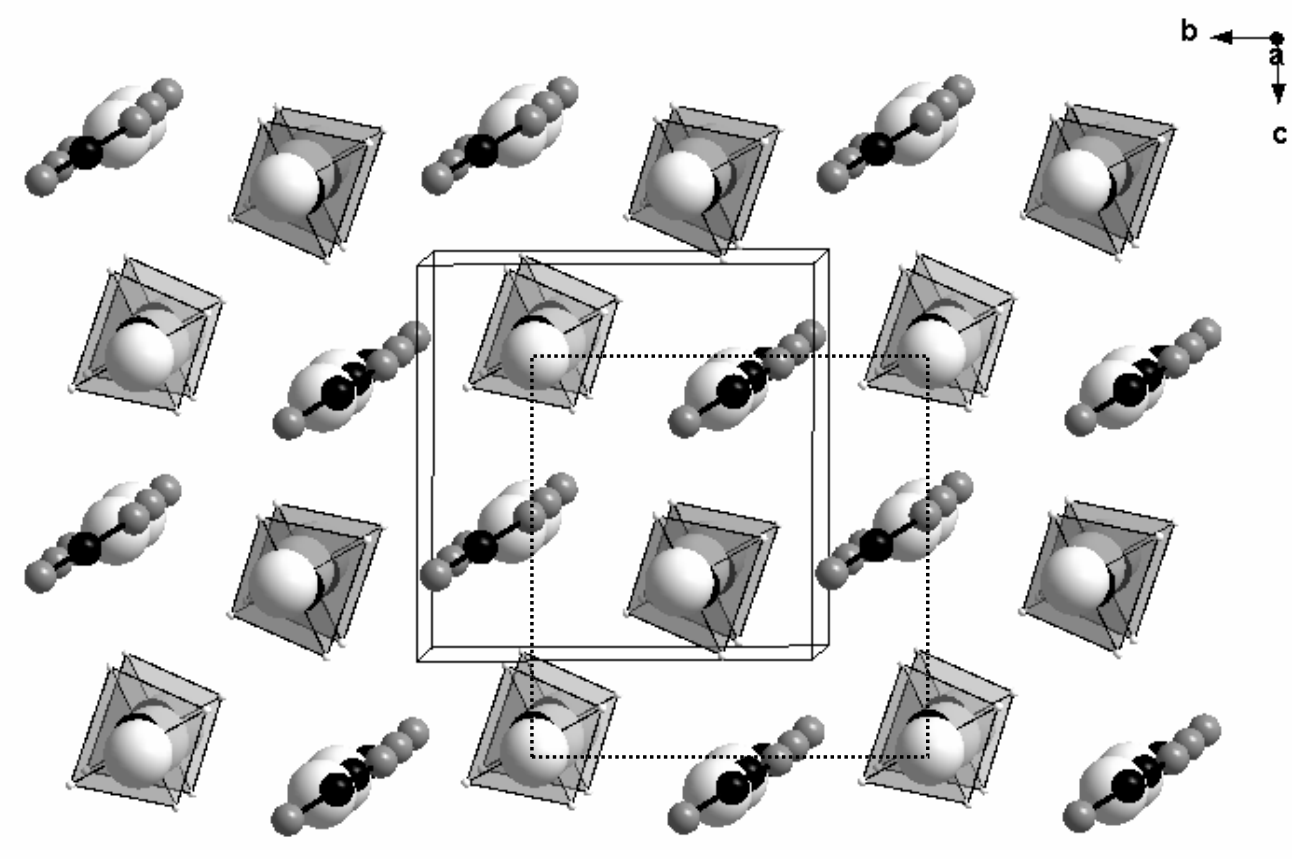

Figure 2. Crystal structure of $\operatorname{Pr}_{2}\left(\mathrm{CN}_{2}\right)\left(\mathrm{SiO}_{4}\right)$. The $\mathrm{NaCl}$ type related unit cell is indicated by the dotted line, with Pr2 at the corner. 


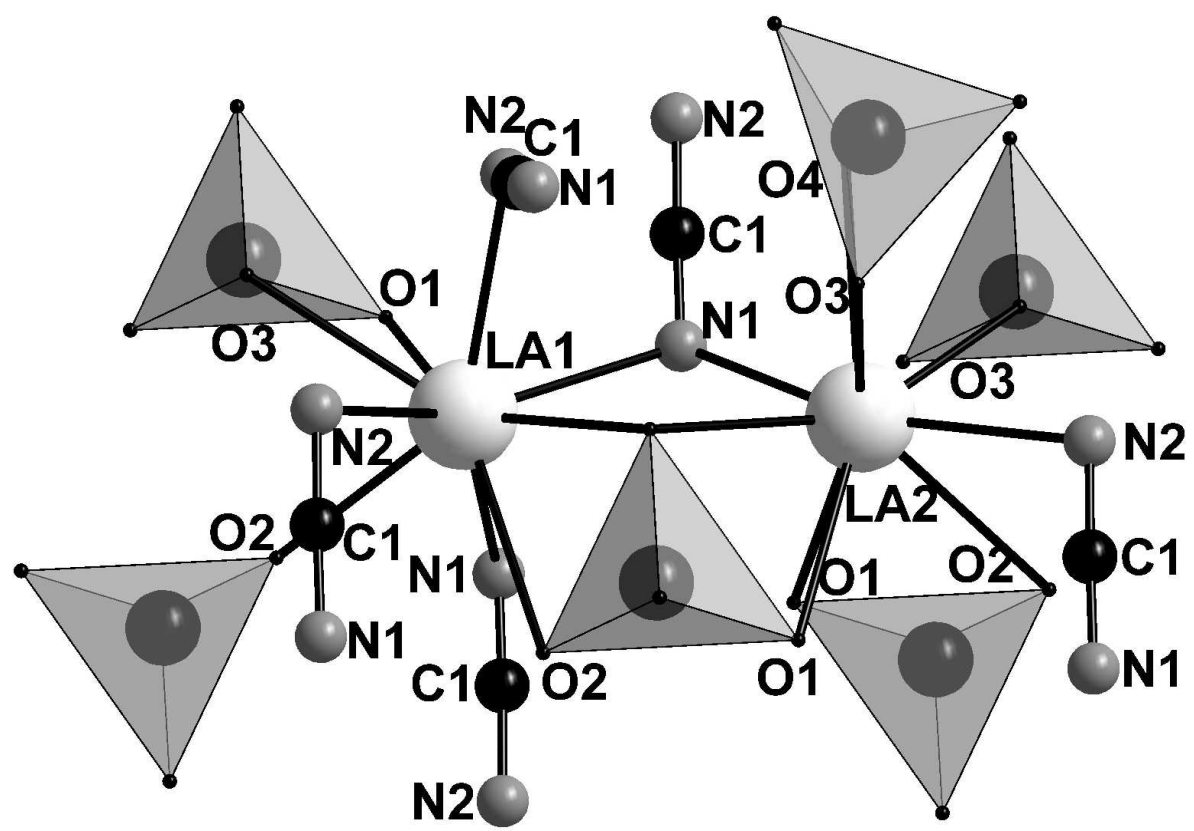

Figure 3. Coordination environment of lanthanum ions in the structure of $\mathrm{La}_{2}\left(\mathrm{CN}_{2}\right)\left(\mathrm{SiO}_{4}\right)$.

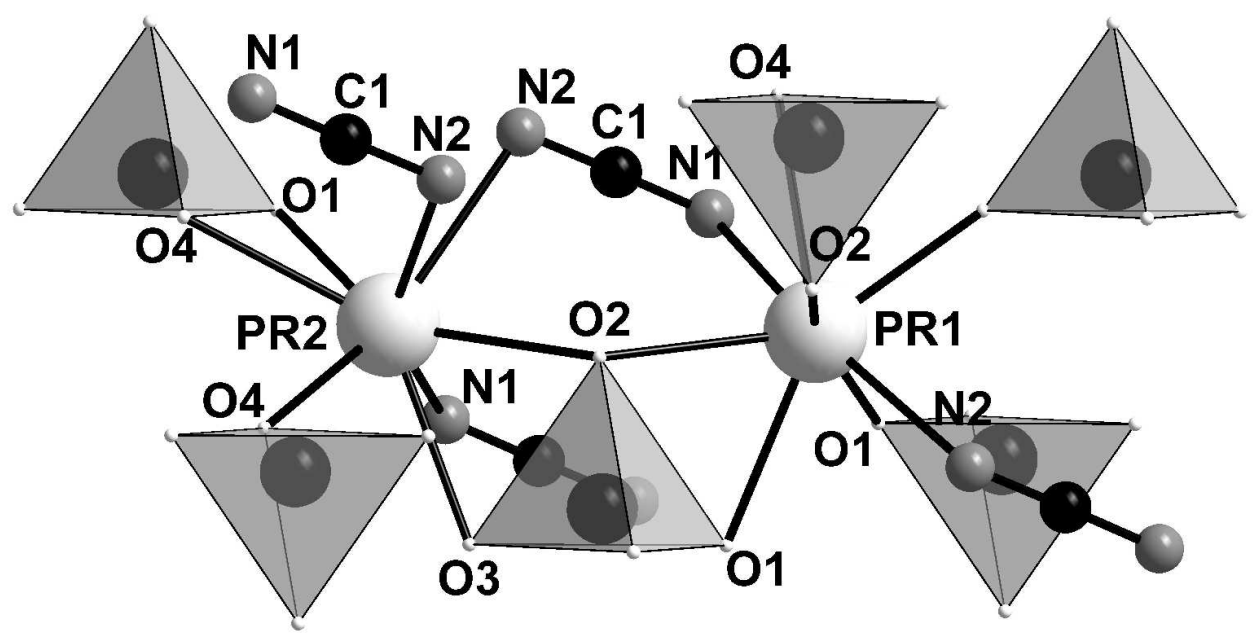

Figure 4. Coordination environment of praseodymium ions in the structure of $\operatorname{Pr}_{2}\left(\mathrm{CN}_{2}\right)\left(\mathrm{SiO}_{4}\right)$. 